\title{
Sex-Dependent Variations in Anti-Nociceptive and Antipyretic Effects of Rhizome and Stem Extract of Schumannianthus dichotomus Roxb. in Male and Female Mice
}

\author{
Md. Rafiul Hoque, Roni Roy, Sazzad Hosen, Irin Karim, Tanaya Bhowmik, Afroza Akter, Mohammad \\ Anwarul Basher*
}

Department of Pharmacy, Noakhali Science and Technology University, Sonapur, Noakhali-3814, Bangladesh.

\begin{tabular}{|c|c|}
\hline Info Article & ABSTRACT \\
\hline Submitted: $19-08-2020$ & Schumannianthus dichotomus (Roxb.) is a perennial shrub from \\
\hline Revised: $14-10-2020$ & Marantaceace family. In traditional medicine, rhizome of the plant is used in \\
\hline Accepted: $31-12-2020$ & and stem is used in earache. We aimed to substantiate these therapeutic \\
\hline *Corresnonding author & claims by examining their effects in mice model. Antinociceptive effect was \\
\hline Mohammad Anwarul & evaluated by three pain models and antipyretic effect was tested by yeast \\
\hline Basher & $\begin{array}{l}\text { induced hyperthermia experiment. Influence of mice sexes on these } \\
\text { pharmacological effects was examined by performing experiments separately }\end{array}$ \\
\hline Email: & on male and female mice. Quantitative analyses of total phenols and \\
\hline m.anwar.basher@gmail.co & flavonoids were performed. Antinociceptive effects showed striking sex \\
\hline & dimorphism. In hind paw licking test, male mice showed significant \\
\hline & reductions in licking in both phases for both rhizome and stem extracts while \\
\hline & significant effect was observed only in late phase in female mice. In writhing \\
\hline & stem was more effective than rhizome in male mice while female mice \\
\hline & produced little effect for both extracts. Antipyretic experiment also showed \\
\hline & $\begin{array}{l}\text { varied effect in male and female mice; both extracts showed significant } \\
\text { decrease in body temperatures. Rhizome showed greater effect in female }\end{array}$ \\
\hline & mice while stem was more effective in male mice. Total phenol and flavonoid \\
\hline & in rhizome were found $103.08 \mathrm{mg} \mathrm{GAE}$ (gallic acid equivalent) and $9.07 \mathrm{mg} \mathrm{QE}$ \\
\hline & cetin equivalent) respectively while in stem, these were $43.39 \mathrm{mg}$ GAE \\
\hline & 0.93 QE. Antinociceptive and antipyretic effects of rhizome and stem \\
\hline & dorsed the traditional uses of $S$. dichotomus. Also, differential \\
\hline & $\begin{array}{l}\text { based on mouse sex indicate the prerequisite of both male and female } \\
\text { nodel in therapeutic evaluations of plant extract. }\end{array}$ \\
\hline & $\begin{array}{l}\text { Keywords: Schumannianthus dichotomus, swiss albino mice, sex } \\
\text { dimorphism, antinociceptive, antipyretic }\end{array}$ \\
\hline
\end{tabular}

\section{INTRODUCTION}

Schumannianthus dichotomus (Roxb.) Gagnep is a perennial shrub belongs to Marantaceace family (Mandal et al., 2014). There are three species in genus Schumannianthus and the species are- Schumannianthus virgatus, Schumannianthus monophyllus and Schumannianthus dichotomus. Rhizome extract of $S$. virgatus was reported to possess hepatoprotective activity (Neethu et al., 2017) while no reports on pharmacological investigations on $S$. monophyllus and $S$. dichotomus have been found. The plant- $S$. dichotomus is normally $3-5 \mathrm{~m}$ high with a basal diameter of $2-5 \mathrm{~cm}$ and grows mainly in clay or clay- loam soil of swampy wetlands with shade ambience (Ahmed et al., 2007). The species has widespread presence in countries of South and South-East Asia including India, Bangladesh, Myanmar, Vietnam, Malaysia and Indonesia (Ahmed et al., 2007; Veldkamp \& Turner, 2016). Traditional uses of plant parts of $S$. dichotomus against various ailments are well documented; rhizome is used against fever and skin diseases and stem is in the treatment of earache (Maneenoon et al., 2015; Sajib \& Uddin, 2015).

Fever and pain are the most common manifestations in diverse disease conditions. A wide variety of drugs are available in pain, 
inflammation and fever but their uses are often accompanied by undesirable side effects. For example, common non-steroidal anti-inflammatory drugs cause gastric disturbances and long-term use of narcotic analgesics is penalized with addiction and dependency. Despite incredible advancement in synthetic chemistry ensuring prolific supply of promising drug candidates, plants are still an attractive source for new bioactive compounds against various diseases. Folkloric uses of plants against different diseases act as a pivot to explore those plants for new bioactive compounds and affirmative activities of crude plant extracts usher identification and isolation of many compounds. For instance, in recent years, several compounds from plant sources have been reported to possess antinociceptive (Mizokami et al., 2012; Nieto et al., 2013; Sun et al., 2019) and antipyretic effect (Lee et al., 2019; Muhammad et al., 2019). A good number of plants native to Bangladesh have been traditionally used against pain and fever and their effects are underpinned by experimental findings in animal model (Ferdous et al., 2020; Roy et al., 2019; Subedi et al., 2016).

Mice, rats and other vertebrates such as rabbits, guinea pigs, cats, dogs, monkeys, etc. play key role in mammalian genetic and biomedical research. Among these animal models, the mouse is deemed the most instrumental model organism because of high ( 95\%) DNA coding sequence conservation with human genomes (Lander et al., 2001; Waterston et al., 2002). Moreover, mutant and inbred mice often demonstrate syndromes that resemble to human inherited diseases due to metabolic and internal anatomical similarities. In 2017, around 61\% experimental studies use mouse model in the field of life science researches in European countries (Report from the Commission to the European Parliament and the council, 2020). In designing experimental studies using mice model, many researchers prefer males assuming female animals would show greater variability due to their changing hormonal state during oesterous cycle; this cyclic hormonal fluctuations not only influence reproductive system but also other physiological systems; thus, the magnitude of responses due to an experimental factor may differ across the cycle (Beery \& Zucker, 2011; Wald \& Wu, 2010). There are numerous reports that reveals significant differences between male and female mice in nociception (Ballou et al., 2000; Dina et al., 2001; Karim et al., 2020), body temperature (SanchezAlavez et al., 2011; Wei et al., 2018), energy intake (Nishikawa et al., 2007), insulin secretion (Suzuki et al., 2017), liver function (Mohar et al., 2014; Spruss et al., 2012), neuroanatomy (An et al., 2011), etc.

In this work, firstly, we aimed to verify folkloric uses of $S$. dichotomus against pain and fever by providing scientific evidences on their claimed activities. Antinociceptive activity was examined by three experiments- formalin induced hind paw licking, acetic acid induced writhing and hot plate test, and activity against fever was evaluated by yeast induced hyperthermia test. All these experiments were conducted on Swiss albino mice model. Secondly, we investigated possible variations in putative antinociceptive and antipyretic effects of the plant extracts in male and female mice.

\section{MATERIALS AND METHODS \\ Preparation of plant extracts}

Whole plant of Schumannianthus dichotomus was collected from Sonapur, Noakhali, Bangladesh. An herbarium specimen (Accession No.: DACB55914) was made and deposited at National Herbarium, Dhaka, Bangladesh. After collection, stem and rhizome were then cut into small pieces, air-dried at room temperature and finally grinded into powder. About $800 \mathrm{~g}$ stem and rhizome material was taken in separate flat bottom glass containers and mixed with two times volume $(\mathrm{w} / \mathrm{v})$ of methanol (80\%) at room temperature. Soaking with methanol was done for two weeks with occasional shaking and stirring. The mixtures were then filtered using filter cloth first followed by filtration through Whatman filter paper No. 1 and concentrated with rotary evaporator producing two different gummy concentrates. Percentage yield of greenish black colored stem concentrate was $1.36 \%(\mathrm{w} / \mathrm{w})$ while rhizome extract was light brown coloured and yield was $1.86 \%(\mathrm{w} / \mathrm{w})$.

\section{Drugs and chemicals}

Standard drugs - diclofenac sodium (99.5\%$100 \%)$, ketorolac (99.0\%-99.8\%) and paracetamol (99.9\%-100\%) were collected from Silva Pharmaceuticals Limited, Noakhali, Bangladesh. Methanol and formaldehyde solution (37\%) were purchased from local vendor of Merck, Germany. Saline solution $(0.9 \% \mathrm{NaCl})$ used to prepare Baker's yeast was a product of Beximco Pharmaceuticals Limited, Bangladesh.

\section{Grouping of animals and dose of samples \\ Prior approval regarding animal model was taken from Institutional Ethics Committee}


(Approval ID. 17/2019). Both male and female Swiss albino mice $(25-30 \mathrm{~g})$ were obtained from International Centre for Diarrhoeal Disease Research, Dhaka, Bangladesh. They were kept in polycarbonate cages with stainless steel grid as lid $(40 \mathrm{x} 30 \times 17 \mathrm{~cm})$ under naturally illuminated environment of $12 / 12 \mathrm{~h}$ dark/light cycle. Temperature and humidity of the animal house was maintained at $23-25^{\circ} \mathrm{C}$ and $50-55 \%$ respectively. The animals got free access to formulated pellet feed and water during entire study period. Mice were acclimatized with the laboratory environment for one week before commencement of experiments. In all experiments, mice of each sex were divided into four groups having six mice per group and the experiments were performed on male and female mice separately. Groups were named as control (water, $10 \mathrm{~mL} / \mathrm{kgBW}$ ), standard (based on experiment), SD200 (extract at dose of $200 \mathrm{mg} / \mathrm{kg} \mathrm{BW}$ ) and SD400 (extract at dose of $400 \mathrm{mg} / \mathrm{kg} \mathrm{BW}$ ). Plant samples were prepared by dissolving the crude extracts in distilled water.

\section{Acute oral toxicity study}

Acute oral toxicity study was performed according to Organization for Economic Cooperation and Development guidelines prior to antinociceptive and antipyretic experiments (OECD, 2001). Doses of plant extracts used were gradually increased from 5 to $2000 \mathrm{mg} / \mathrm{kg}$ BW (50 and $300 \mathrm{mg} / \mathrm{kg}$ BW as intermediate doses). The animals were observed for 14 days for any change of general behavior, food and water intake, salivation, frequency of defecation, any manifestation of toxicity, etc. During this examination period, no mortality and moribundity of animals were observed; hence, one-fifth and onetenth of maximum administered dose i.e. $2000 \mathrm{mg} / \mathrm{kg}$ BW were considered safe to conduct anti-nociceptive and antipyretic experiments.

\section{Anti-nociceptive activity}

\section{Formalin induced hind paw licking test}

In formalin induced licking test, $0.02 \mathrm{~mL}$ of $2.5 \%$ formalin was used as algogen and was injected subcutaneous (s.c.) into the plain surface of left hind paw of mouse (Dubuisson \& Dennis, 1977; Wheeler-Aceto et al., 1990). Control group received $10 \mathrm{~mL} / \mathrm{kg}$ BW distilled water while diclofenac $(10 \mathrm{mg} / \mathrm{kg} \mathrm{BW})$ was administered in standard group. All test samples were administered (p.o.) oral administration $1 \mathrm{~h}$ before this injection. Licking and biting of the injected paw were considered as nocifensive behaviours. Time spent in licking and biting was recorded in two phases: at first $0-5 \mathrm{~min}$ and last $15-30 \mathrm{~min}$ after formalin injection. The results were expressed as percent inhibition of licking response (PIL):

$\% \mathrm{PIL}=\left(\frac{\mathrm{TSL} \text { (control) }-\mathrm{TSL} \text { (standard or extract) }}{\mathrm{TSL} \text { (control) }}\right) \mathrm{X} 100$

TSL $=$ Time spent licking

\section{Acetic acid induced writhing test}

In this experiment, induction of nociception such as abdominal constriction, caudal elongation along the abdominal wall, etc. was achieved by administration of $0.6 \%$ acetic acid (i.p.) intraperitoneal (Collier et al., 1968; Siegmund et al., 1957). Plant extracts, diclofenac (10mg/kg BW) and control (water, $10 \mathrm{~mL} / \mathrm{kg} \mathrm{BW}$ ) were administered (p.o.) $30 \mathrm{~min}$ before administration of acetic acid. Number of writhes (squirming of the trunk and/or pelvis, elongation of the body, extension of the hind limbs) was recorded for $15 \mathrm{~min}$. Results were expressed as mean percent inhibition of writhing (PIW):

$\% \mathrm{PIW}=\left(\frac{\mathrm{NW}_{\text {(control) }}-\mathrm{NW}_{\text {(standard or extract) }}}{\mathrm{NW}_{\text {(control) }}}\right) \mathrm{X} 100$

NW=Number of Writhes

\section{Hot plate test}

In hot plate test, temperature of the apparatus was raised and maintained at $55 \pm 0.5^{\circ} \mathrm{C}$ (Woolfe \& Macdonald, 1944). Prescreening of mice was done first by placing each mouse on the hot plate; animals those showed nociceptive responses (licking, jumping, flinching, etc.) within 10 s were selected for final experiment. Water $(10 \mathrm{~mL} / \mathrm{kg}$ BW) and ketorolac (10mg/kg BW) were used in control and standard group respectively. In the final experiment, each mouse was again placed on the hot plate and latency of mice to this thermal stimulus was recorded at $0,0.5,1$ and $2 \mathrm{~h}$ postprandial. Response time was recorded when the animal first licked its paw or started to jump. To avoid mouse tissue damage, 20s was chosen as the cut-off time. Results were expressed as mean percent maximal effect (\% MPE):

$\%$ MPE $=\left(\frac{\text { Post DL }(t h r)-\operatorname{Pre~DL}(0 h)}{\text { Cut-off time-Pre DL }(0 h)}\right) \times 100$

DL=drug latency

\section{Antipyretic activity}

Antipyretic effect of the extract was determined by inducing hyperthermia in mice (Tomazetti et al., 2005). Elevated body temperature of mice was achieved by injecting $20 \%$ 
Baker's yeast suspended in $0.9 \%$ saline at a dose of $10 \mathrm{~mL} / \mathrm{kg}$ BW. Rectal temperature was measured using a digital thermometer with its probe lubricated with glycerin. After measuring the rectal temperature and yeast injection, mice were kept in fasting condition for 18h; animals those showed an elevated body temperature of $1.5^{\circ} \mathrm{F}$ was selected for the final experiment. The selected animals were then treated (p.o.) with water $(10 \mathrm{~mL} / \mathrm{kg} \mathrm{BW}$, control group), paracetamol $(150 \mathrm{mg} / \mathrm{kg}$ BW, standard group) and plant extracts (200 and $400 \mathrm{mg} / \mathrm{kg}$ BW). Rectal temperatures of all experimental animals were measured at intervals of $0,0.5,1,2,3$ and $4 \mathrm{~h}$.

\section{Phytochemical analysis}

Qualitative analyses of major phytoconstituents in methanol extract of rhizome and stem were carried out using standard procedures (Evans, 2009). Quantitative determination of phenolics, tannins and flavonoids were performed as described in Akter, 2019 (Akter et al., 2019).

\section{Analysis of data}

Statistical software GraphPad prism (version 8.4) was used for data analysis. Data were presented as mean \pm SEM. A probability level of 0.05 (adjusted $p$ value) or less was accepted as significant; ${ }^{*} \mathrm{p} \leq 0.05,{ }^{* *} \mathrm{p} \leq 0.01,{ }^{* * *} \mathrm{p} \leq 0.001$ vs. control of the respective experiment.

\section{RESULT AND DISCUSSION \\ Anti-nociceptive activity \\ Formalin induced hind paw licking test}

The effect of plant extracts on formalin induced hind paw licking (Figure 1). Significant decrements in licking duration as an indication of antinociception were observed by both rhizome and stem extract at higher dose in male mice model. In female mice model, both extracts produced little effect in early phase of the experiment while significant effects were observed in late phase.

In early phase of the experiment, in male mice model, standard showed licking duration of 73s whereas control group exhibited 85.5s. Plant samples produced stronger effect than diclofenac in a dose dependent manner; rhizome and stem extract at $400 \mathrm{mg} / \mathrm{kg}$ BW reduced the propensity to lick to $35.3 \mathrm{~s} \quad(\mathrm{p}<0.05)$ and $29.9 \mathrm{~s} \quad(\mathrm{p}<0.01)$ respectively while lower dose also superseded diclofenac and durations were $60.4 \mathrm{~s}$ and $55.9 \mathrm{~s}$ for rhizome and stem respectively. In the late phase, licking durations of control, diclofenac, both doses of rhizome extract and $200 \mathrm{mg} / \mathrm{kg}$ BW stem extract were increased indicating attenuation of antinociceptive effect over time; nonetheless, stem extract at $400 \mathrm{mg} / \mathrm{kg}$ BW retained its activity. Percent inhibition of licking is the indication of antinociceptive potentiality of extracts compared with control group. In the early phase, diclofenac inhibited $14.62 \%$ whereas rhizome and stem at $200 \mathrm{mg} / \mathrm{kg}$ BW demonstrated $29.36 \%$ and $34.62 \%$ inhibition; higher extract doses showed greater effects producing $58.83 \%$ and $65.03 \%$ inhibition. In the late phase, inhibition by rhizome at 400 $\mathrm{mg} / \mathrm{kgBW}$ dose was increased slightly to $61.29 \%$ while stem extract at the same dose produced substantial amelioration in antinociception and inhibited $80.52 \%$.

In case of female mice model, in early phase of the experiment, the extracts did not produce noticeable change in licking duration compared to control group. Licking durations of control and standard were $69.1 \mathrm{~s}$ and $38.8 \mathrm{~s}$ respectively. Hence, diclofenac showed $43.85 \%$ inhibition in licking in early phase while both rhizome and stem extracts demonstrated little effect producing less than $10 \%$ inhibition. In late phase of the test, standard drug and extracts showed significant decrease $(p<0.001)$ in licking. Rhizome and stem extracts of both doses showed greater effect than diclofenac (55.94\%); rhizome at $200 \mathrm{mg} / \mathrm{kgBW}$ and $400 \mathrm{mg} / \mathrm{kg}$ BW demonstrated $69.5 \%$ and $69.16 \%$ inhibition while stem at the same doses produced $64.69 \%$ and $73.06 \%$ inhibition.

\section{Acetic acid induced writhing test}

Inhibition of writhing responses upon administration of standard drug and plant extracts (Table I). The extracts demonstrated dosedependent attenuation of nociception. Stem extract produced stronger effect than rhizome in both male and female mice and in all doses, male mice demonstrated better antinociceptive response than female mice.

Rhizome extract at $200 \mathrm{mg} / \mathrm{kg}$ BW reduced writhes from 41.0 to 24.7 ( $\mathrm{p}<0.1,39.75 \%$ inhibition) in male mice while little reduction in number of writhes by 3.2 (5.75\%) was observed in female mice at the same dose. Stem extract at $200 \mathrm{mg} / \mathrm{kg}$ BW was observed more potent in both male and female than rhizome extract; percentage inhibitions were $77.63 \%$ and $56.55 \%$ for male and female respectively. Increasing the dose at $400 \mathrm{mg} / \mathrm{kgBW}$, number of writhes in male mice were $12.3(p<0.001)$ and $7.67(\mathrm{p}<0.001)$ for rhizome and stem respecttively producing $70 \%$ and $81.29 \%$ inhibition. 


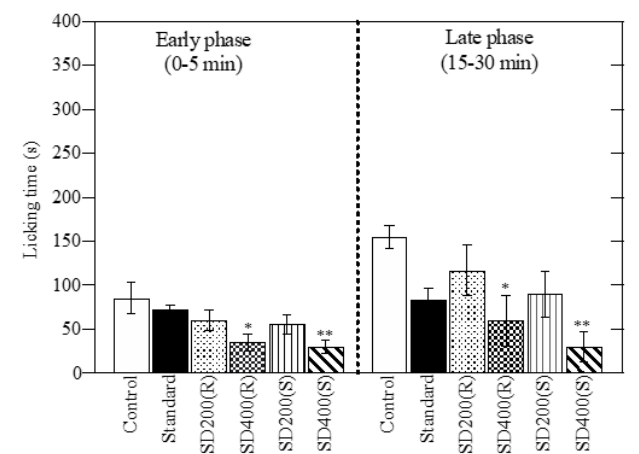

Male mice model

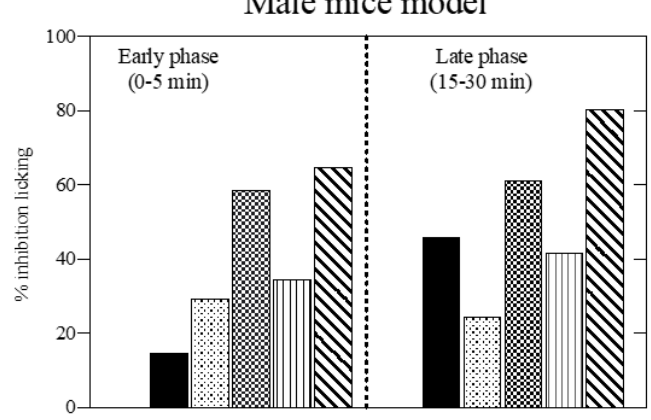

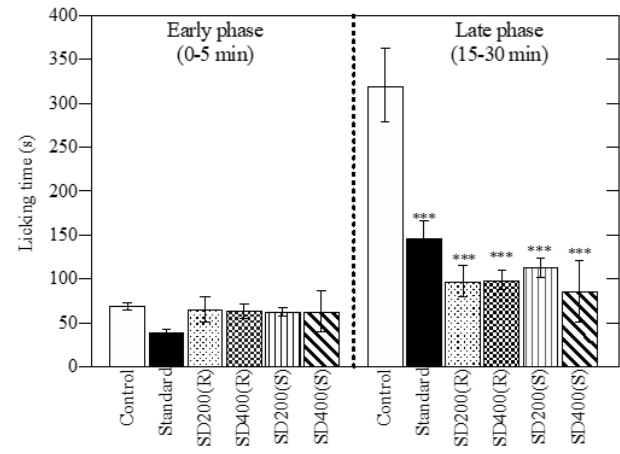

Female mice model

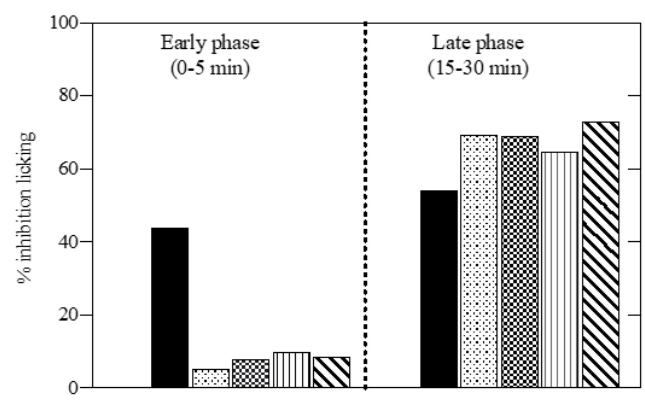

Figure 1. Effect of rhizome and stem extract of Schumannianthus dichotomus in formalin induced hind paw licking test in male and female mice model. Data were presented as Mean \pm SEM. One-way ANOVA with Dunnett multiple comparisons test was performed to determine statistical significance of test results; here, ${ }^{*} \mathrm{p}<0.05,{ }^{* *} \mathrm{p}<0.01$ and ${ }^{* * *} \mathrm{p}<0.001$ vs control.

Table I. Effect of methanol extract of rhizome and stem of $S$. dichotomus on the number of writhing responses in acetic acid induced writhing test.

\begin{tabular}{lcccc}
\hline \multirow{2}{*}{ Group } & \multicolumn{1}{c}{ Male } & \multicolumn{2}{c}{ Female } \\
\cline { 2 - 5 } & Writhes response & PIW & Writhes response & PIW \\
\hline Control & $41.0 \pm 4.75$ & - & $55.7 \pm 4.47$ & - \\
Standard & $21.0 \pm 2.31^{*}$ & 48.78 & $19.2 \pm 5.10^{* * *}$ & 65.53 \\
SD200(R) & $24.7 \pm 7.86^{*}$ & 39.75 & $52.5 \pm 4.84$ & 5.75 \\
SD400(R) & $12.3 \pm 2.09^{* * *}$ & 70.00 & $35.3 \pm 5.48^{*}$ & 36.62 \\
SD200(S) & $9.17 \pm 1.74^{* * *}$ & 77.63 & $24.2 \pm 4.79^{* * *}$ & 56.55 \\
SD400(S) & $7.67 \pm 3.71^{* * *}$ & 81.29 & $15.8 \pm 2.30^{* * *}$ & 71.63 \\
\hline
\end{tabular}

'SD' stands for Schumannianthus dichotomus; (R) for rhizome and (S) for stem. Data were presented as mean \pm SEM. All data were analyzed using ANOVA followed by Dunnett's test for multiple comparisons of means. Significantly different from control at ${ }^{*} \mathrm{p}<0.05,{ }^{* * *} \mathrm{p}<0.001$.

At the same dose, female mice showed $36.62 \%$ and $71.63 \%$ inhibition for rhizome and stem respectively. Standard drug- diclofenac produced $48.78 \%$ and $65.53 \%$ inhibition for male and female respectively.

\section{Hot plate test}

In hot plate test, dose dependent significant increase in tolerance against thermal stimuli was observed in male mice for both rhizome and stem extract. However, stem extract was found more potent than rhizome. On contrary, little antinociceptive activity was evident in female mice for both extracts (Figure 2).

In case of male mice, standard drugketorolac significantly $(\mathrm{p}<0.001)$ increased latency from $10.27 \mathrm{~s}$ to $16.56 \mathrm{~s}, 17.26 \mathrm{~s}$ and $18.4 \mathrm{~s}$ after $0.5 \mathrm{~h}$, $1 \mathrm{~h}$ and $2 \mathrm{~h}$ respectively. Stem at $400 \mathrm{mg} / \mathrm{kg} \mathrm{BW}$ raised the latency significantly $(\mathrm{p}<0.01)$ from 11.08 $\mathrm{s}$ to $15.81 \mathrm{~s}$ after $0.5 \mathrm{~h}$ and the tolerance was further increased after $2 \mathrm{~h}$ to $17.36 \mathrm{~s}$. At $200 \mathrm{mg} / \mathrm{kgBW}$ stem extract, latency was increased by $3.5 \mathrm{~s}(\mathrm{p}<0.01)$ 
within $0.5 \mathrm{~h}$ but increased little afterwards. In case of rhizome extract, both SD200 and SD400 showed increased latency after $0.5 \mathrm{~h}$, then reduced it slightly after $1 \mathrm{~h}$ that again augmented after $2 \mathrm{~h}$ and increases in latency after $2 \mathrm{~h}$ were $2.03 \mathrm{~s}(\mathrm{p}<0.05)$ and $2.78 \mathrm{~s}(\mathrm{p}<0.01)$ for $200 \mathrm{mg} / \mathrm{kg}$ BW and 400 $\mathrm{mg} / \mathrm{kg} \mathrm{BW}$ respectively. For stem extract in female mice, significant change $(p<0.05)$ in latency was observed for both doses after $1 \mathrm{~h}$ though latencies were briefly elevated from $4.32 \mathrm{~s}$ to $5.01 \mathrm{~s}$ for $200 \mathrm{mg} / \mathrm{kg} \mathrm{BW}$ and $4.2 \mathrm{~s}$ to $4.85 \mathrm{~s}$ for $400 \mathrm{mg} / \mathrm{kg}$ BW. Activity of similar extent was observed for rhizome extract and increased the latency by $0.52 \mathrm{~s}$ and 1.86 $\mathrm{s}$ after $2 \mathrm{~h}$ for $200 \mathrm{mg} / \mathrm{kg}$ BW and $400 \mathrm{mg} / \mathrm{kg}$ BW respectively.

Quantitative assessment of antinociceptive potentials for rhizome and stem was done by calculating mean percent maximal effect from duration of latency at different time intervals (equation mentioned in section 2.4.2). For male mice, standard compound produced rapid and prominent effect (64.6\%) immediately after $0.5 \mathrm{~h}$ that subsequently increased as time elapsed showing $83.55 \%$ effect after $2 \mathrm{~h}$. Stem extract at 400 $\mathrm{mg} / \mathrm{kg} \mathrm{BW}$ dose demonstrated $70.35 \%$ effect after $2 \mathrm{~h}$ whereas lower dose $(200 \mathrm{mg} / \mathrm{kg} \mathrm{BW})$ produced effect around $40 \%$ throughout the experiment. As rhizome extract exhibited little increase in latency compared to stem, hence produced maximal $25.7 \%$ and $31 \%$ effect at $200 \mathrm{mg} / \mathrm{kg} \mathrm{BW}$ and $400 \mathrm{mg} / \mathrm{kg}$ BW respectively. In female mice, standard drug showed $31.13 \%$ effect whereas both rhizome and stem extracts exhibited minute effect. Rhizome showed $3.28 \%$ and $12.4 \%$ for 200 and $400 \mathrm{mg} / \mathrm{kg}$ BW after $2 \mathrm{~h}$ whereas for stem, the effects were $9.61 \%$ and $5.68 \%$ respectively after same time span.

\section{Antipyretic activity}

Reduction in mice body temperature from Baker's yeast induced fever (Table II). Both rhizome and stem extracts demonstrated significant antipyretic effect but varied in magnitude of reduction. Rhizome showed greater antipyretic effect in female mice while stem extract was more effective in male mice.

For rhizome extract, female mice at $200 \mathrm{mg} / \mathrm{kg}$ BW showed greater antipyretic effect than higher dose $(400 \mathrm{mg} / \mathrm{kg} \mathrm{BW})$; the results were consistent from $0.5 \mathrm{~h}$ to $4 \mathrm{~h}$. For instance, after $0.5 \mathrm{~h}$, decrements in temperature were $2.13^{\circ} \mathrm{F}(\mathrm{p}<0.05)$ and $1.05^{\circ} \mathrm{F} \quad(\mathrm{p}<0.05)$ for $200 \mathrm{mg} / \mathrm{kg} \quad \mathrm{BW}$ and $400 \mathrm{mg} / \mathrm{kg}$ BW respectively while after $4 \mathrm{~h}$, the reductions were $2.95^{\circ} \mathrm{F} \quad(\mathrm{p}<0.05)$ and $2.48^{\circ} \mathrm{F}$
( $p<0.001$ ). On the other hand, for rhizome extract, the male mice experienced greater reductions at higher dose as time elapsed; for $2 \mathrm{~h}, 3 \mathrm{~h}$ and $4 \mathrm{~h}, \mathrm{SD}$ 400 reduced body temperatures by $1.90^{\circ} \mathrm{F}$ $(\mathrm{p}<0.05), 2.30^{\circ} \mathrm{F}(\mathrm{p}<0.05)$ and $1.72^{\circ} \mathrm{F}(\mathrm{p}<0.001)$ whereas for $200 \mathrm{mg} / \mathrm{kg}$ BW, these lowered by $1.83^{\circ} \mathrm{F} \quad(\mathrm{p}<0.01), \quad 1.65^{\circ} \mathrm{F} \quad(\mathrm{p}<0.01)$ and $1.17^{\circ} \mathrm{F}$ $(p<0.001)$ respectively. The same result was observed for stem extract where body temperatures in male mice reduced at greater degree at $400 \mathrm{mg} / \mathrm{kg}$ BW than at $200 \mathrm{mg} / \mathrm{kg}$ BW. Maximum reduction by $3.15^{\circ} \mathrm{F}$ was observed after $2 \mathrm{~h}$ for $400 \mathrm{mg} / \mathrm{kg}$ BW while extract at $200 \mathrm{mg} / \mathrm{kg}$ $\mathrm{BW}$ reduced it by $1.93^{\circ} \mathrm{F}(\mathrm{p}<0.001)$ after $4 \mathrm{~h}$. Female mice was found to follow similar trend as increased stem extract concentration showed better antipyretic effect except at $0.5 \mathrm{~h}$. Maximal effect was observed after $4 \mathrm{~h}$ when temperature was reduced by $2.20^{\circ} \mathrm{F}(\mathrm{p}<0.001)$ at $400 \mathrm{mg} / \mathrm{kg} \mathrm{BW}$; after the same time span, extract at $200 \mathrm{mg} / \mathrm{kg} \mathrm{BW}$ decreased body temperature by $1.68^{\circ} \mathrm{F}(\mathrm{p}<0.001)$.

\section{Phytochemical analysis}

Qualitative phytochemical screening of methanolic extract of rhizome and stem showed the presence of phenols, tannins, flavonoids, alkaloids, carbohydrates and phytosterols. Proteins were observed only in stem while rhizome showed the presence of terpenes. Glycosides, saponins and gums were not observed in both rhizome and stem. Total phenolic contents in rhizome and stem were found $103.08 \mathrm{mg} \mathrm{GAE}$ and $43.39 \mathrm{mg}$ GAE per $\mathrm{g}$ of extract respectively while flavonoid contents were $9.07 \mathrm{gm} \mathrm{QE}$ and $20.93 \mathrm{QE}$ per $\mathrm{g}$ of extract.

Qualitative phytochemical screening of methanol extract of $S$. dichotomus demonstrated that rhizome and stem extracts contain similar phytochemicals. Quantitative analyses showed that total phenol content was present in greater amount in rhizome than in stem while flavonoid content was higher in stem. Numerous researches on different plants reported diverse pharmacological effects including antinociceptive, antiinflammatory and antipyretic effects of phenols (Boussouf et al., 2017; Gomathi \& Manian, 2015; Nguyen et al., 2017) and flavonoids (Chen et al., 2016; Owoyele et al., 2008; Wang et al., 2014). As rhizome and stem extract of $S$. dichotomus possess similar phytoconstituents; hence, both extracts are anticipated to show analogous effects. And, different contents of total phenols and flavonoids in rhizome and stem correspond to their varied degree of antinociceptive and antipyretic effects. 


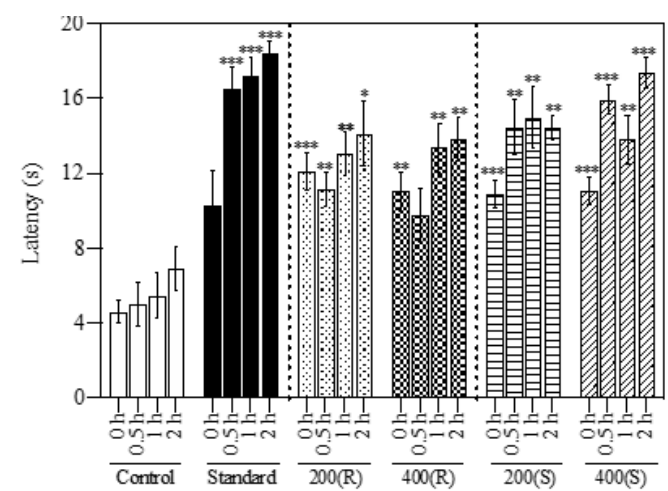

Male mice model

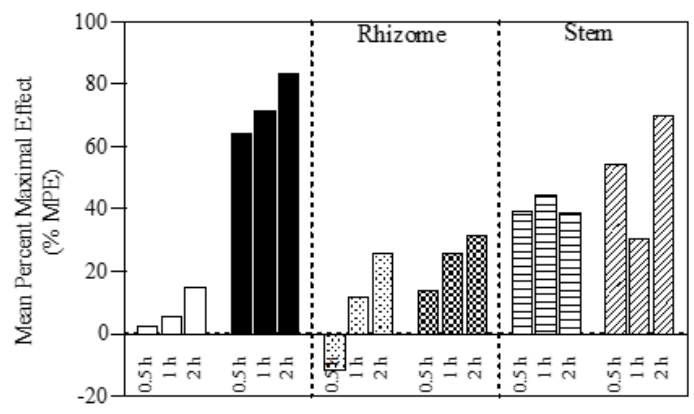

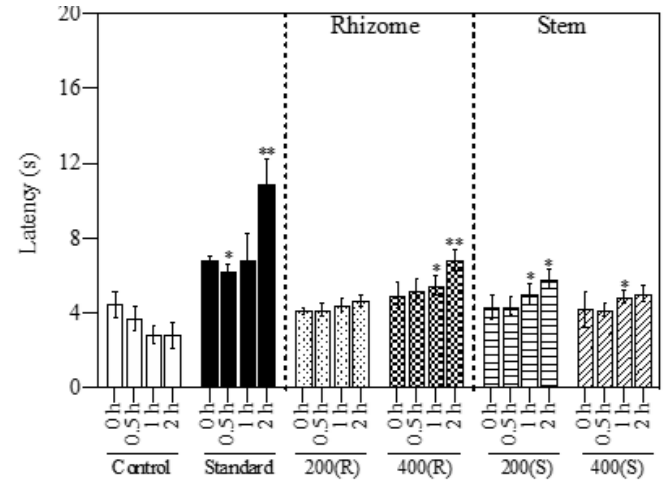

Female mice model

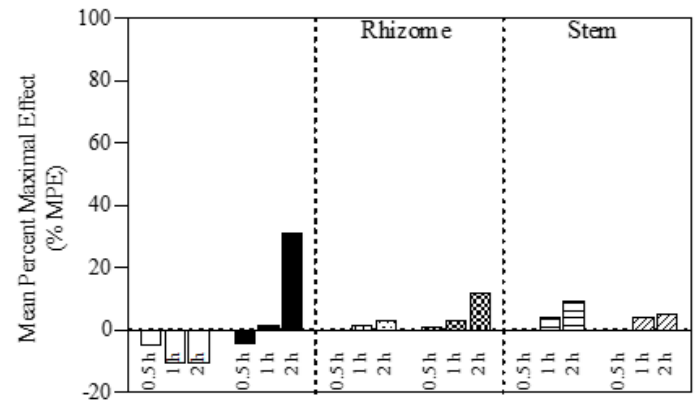

Figure 2: Effect of rhizome and stem extract of Schumannianthus dichotomus against thermally induced pain in male and female mice model. Data were presented as Mean \pm SEM. Two-way ANOVA with Tukey multiple comparisons test was performed to determine statistical significance of test results; here, ${ }^{*} \mathrm{p}<0.05,{ }^{* *} \mathrm{p}<0.01$ and $^{* * *} \mathrm{p}<0.001$ vs control.

Effects against nociception and fever differed not only between extracts but also between sexes of animal. In hind paw licking test, the licking time was recorded in two phases. Significant decrements in licking duration as an indication of antinociception were observed by both rhizome and stem extracts in male mice model. In female mice model, both extracts produced little effect in early phase of the experiment while significant effects were observed in late phase. Generation of pain in licking test is a biphasic event and mediates through independent afferent pathway. Early phase generally involves Cfiber activation producing neurogenic pain and late phase is mainly mediated by various cytokines in the peripheral tissues (Davidson \& Carlton, 1998; Linhart et al., 2003). Centrally acting analgesics and paracetamol like drugs can inhibit equally in both phases; on the other hand, (non-steroidal antiinflammatory drug) NSAIDs such as naproxen and indomethacin are more effective in late phase (Hunskaar \& Hole, 1987). Induction, manifestation and magnitude of nocifensive behaviours show distinct sex dimorphism in mice owing to differences in underlying pathways. In case of early phase, injuries to peripheral nerves to induce pain revealed that microglia accounts for pain sensation in male mice whereas in female mice, one of the immunological components i.e. T cell controls pain (Sorge et al., 2015). In the context of proinflammatory cytokine mediators such as prostaglandins and leukotrienes, these mediators are conversely regulated by mice sexes. Both mediators are synthesized from same precursor i.e. arachidonic acid but through two different pathways; for leukotrienes, it is lipoxygenase (LOX) pathway while cyclooxygenase (COX) pathway is responsible for production of prostaglandins. In case of female mice, leukotrienes are generated in greater extent than prostaglandins; on the contrary, male mice shows preferential activation of cyclooxygenase (COX) pathway generating prostaglandins (Pace et al., 2017). Selective inhibition of either COX or LOX pathway will display preferential attenuation of pain in any particular sex while indiscrimination between two pathways will result similar antinociceptive effects in both male and female mice. 
Table II. Reduction in body temperatures $\left({ }^{\circ} \mathrm{F}\right)$ in male and female mice in yeast induced febrile condition after administration of rhizome and stem extracts

\begin{tabular}{clcccc}
\hline \multirow{2}{*}{ Time } & \multirow{2}{*}{ Groups } & \multicolumn{2}{c}{ Rhizome } & \multicolumn{2}{c}{ Stem } \\
\cline { 2 - 5 } & & Male & Female & Male & Female \\
\hline \multirow{2}{*}{$0.5 \mathrm{~h}$} & Control & $-0.50 \pm 0.14$ & $-0.53 \pm 0.09$ & $-0.50 \pm 0.14$ & $-0.53 \pm 0.09$ \\
& Standard & $2.58 \pm 1.62^{* * *}$ & $2.33 \pm 0.72^{*}$ & $2.58 \pm 1.62^{* * *}$ & $2.33 \pm 0.72^{*}$ \\
& SD200 & $1.98 \pm 0.56^{*}$ & $2.13 \pm 0.54^{*}$ & $0.73 \pm 0.37$ & $2.17 \pm 0.24$ \\
& SD400 & $1.68 \pm 0.54^{*}$ & $1.05 \pm 0.33^{*}$ & $2.02 \pm 0.77$ & $1.55 \pm 0.75$ \\
\multirow{1}{*}{$\mathrm{h}$} & Control & $-0.28 \pm 0.21$ & $-1.10 \pm 0.22$ & $-0.28 \pm 0.21$ & $-1.10 \pm 0.22$ \\
& Standard & $2.52 \pm 0.26^{* * *}$ & $2.67 \pm 0.44^{* * *}$ & $2.52 \pm 0.26^{* * *}$ & $2.67 \pm 0.44^{* * *}$ \\
& SD200 & $2.35 \pm 0.42^{* *}$ & $2.02 \pm 0.57^{* *}$ & $0.68 \pm 0.43$ & $0.90 \pm 0.46^{*}$ \\
& SD400 & $1.70 \pm 0.42^{*}$ & $1.48 \pm 0.37^{* *}$ & $2.70 \pm 0.93$ & $1.47 \pm 0.77$ \\
$2 \mathrm{~h}$ & Control & $-0.50 \pm 0.31$ & $-1.03 \pm 0.50$ & $-0.50 \pm 0.31$ & $-1.03 \pm 0.50$ \\
& Standard & $2.32 \pm 0.43^{* *}$ & $2.47 \pm 0.55^{* *}$ & $2.32 \pm 0.43^{* *}$ & $2.47 \pm 0.55^{* *}$ \\
& SD200 & $1.83 \pm 0.40^{* *}$ & $2.25 \pm 0.61^{* *}$ & $1.20 \pm 0.33^{*}$ & $0.90 \pm 0.46$ \\
& SD400 & $1.90 \pm 0.56^{*}$ & $2.05 \pm 0.31^{* *}$ & $3.15 \pm 1.05$ & $1.70 \pm 0.76$ \\
3h & Control & $-0.65 \pm 0.31$ & $-1.70 \pm 0.23$ & $-0.65 \pm 0.31$ & $-1.70 \pm 0.23$ \\
& Standard & $3.68 \pm 0.24^{* * *}$ & $1.43 \pm 0.28^{* * *}$ & $3.68 \pm 0.24^{* * *}$ & $1.43 \pm 0.28^{* * *}$ \\
& SD200 & $1.65 \pm 0.44^{* *}$ & $2.77 \pm 0.59^{* *}$ & $0.85 \pm 0.40$ & $1.45 \pm 0.44^{* *}$ \\
& SD400 & $2.30 \pm 0.67^{*}$ & $2.38 \pm 0.30^{* * *}$ & $2.55 \pm 1.19$ & $2.15 \pm 0.72^{* *}$ \\
& Control & $-4.12 \pm 0.54$ & $-1.52 \pm 0.37$ & $-4.12 \pm 0.54$ & $-1.52 \pm 0.37$ \\
& Standard & $3.42 \pm 0.35^{* * *}$ & $1.38 \pm 0.35^{* * *}$ & $3.42 \pm 0.35^{* * *}$ & $1.38 \pm 0.35^{* * *}$ \\
& SD200 & $1.17 \pm 0.38^{* * *}$ & $2.95 \pm 0.98^{*}$ & $1.93 \pm 0.53^{* * *}$ & $1.68 \pm 0.39^{* * *}$ \\
& SD400 & $1.72 \pm 0.71^{* * *}$ & $2.48 \pm 0.38^{* * *}$ & $2.61 \pm 0.61^{* * *}$ & $2.20 \pm 0.43^{* * *}$ \\
\hline
\end{tabular}

SD200 and SD400 represent extract concentrations at $200 \mathrm{mg} / \mathrm{kgBW}$ and $400 \mathrm{mg} / \mathrm{kgBW}$ respectively. Data were presented as Mean \pm SEM. Minus (-) sign indicates elevation in body temperature. Two-way ANOVA with Tukey multiple comparisons test was performed to determine statistical significance of the test results; here, ${ }^{*} \mathrm{p}<0.05$, ${ }^{* *} \mathrm{p}<0.01$ and ${ }^{* * *} \mathrm{p}<0.001$ vs control.

Greater antinociceptive effect in the late phase of licking test indicates that the plant extracts mainly act on inflammatory pathways. Also, higher effect in male mice than female could be an important evidence that phytochemicals in $S$. dichotomus inhibit COX in greater degree over LOX pathway. Preferential effect on pro-inflammatory COX pathway by $S$. dichotomus extract was further substantiated by the findings in acetic acid induced writhing study that showed stronger effect in male mice than female. In writhing test, acetic acid induces release of prostaglandins that results acute inflammation in abdominal cavity; the event in turn stimulates nociceptive sensory nerve endings in the peritoneal area (Sutradhar et al., 2007). Prostaglandins are synthesized in tissues by two cyclooxygenases- COX-1 and COX-2; the former is constitutive in nature while the later one is induced by inflammatory stimuli. Ballou et al reported variable writhing responses in male and female mice due to differences in COX-1 and COX-2 activities (Ballou et al., 2000). In hot plate test, rhizome and stem extracts of $S$. dichotomus showed potent antinociceptive effect in male mice while in female mice, little maximal effects were observed for both extracts. Fatehi et al. reported that inhibition of nitric oxide synthesis by administration of enzyme inhibitor such as $\mathrm{N}^{\mathrm{G}_{-}}$ nitro-L-arginine methyl ester had resulted diminished perception of pain in hot plate test in male mice but not in female (Fatehi-Hassanabad $e t$ al., 2005). It was postulated that thermal stimulus from hot plate stir L-arginine-nitric oxide signalling pathway more prominently in male than in female with possible involvement of sex hormones. Similar experiments in both sexes of rats also demonstrated that inhibitors of nitric oxide synthetase (NOS) antagonized pain only in male and is dependent on sex hormones (Dina et al., 2001). Thus, any phytoconstituent that hinder NOS pathway will render antinociceptive effects preferentially in male mice and rhizome and stem extract must contain bioactive compounds that have some effects on NOS pathway; thus, pain perception is selectively observed in male over female. Thermal stimuli also affect opioid receptors 
manifested as spinal analgesia (Pathan \& Williams, 2012). For opioids, pain is actuated by three types of receptors- $\mu, \kappa$ and $\delta$. Activity of these receptors significantly differ in male and female mice; opioids with $\mu$ and $\kappa$ receptors agonist activity are found more effective in male mice in response to various chemical and thermal fillips while $\delta$ receptor has no preferences over sex (Cicero et al., 1996; Kepler et al., 1991).

Methanol extracts of $S$. dichotomus showed significant antipyretic effect. Both extracts and paracetamol produced a sharp decrease of elevated rectal temperature. Reduction of body temperature by paracetamol involves inhibition of prostaglandin synthesis by blocking cyclooxygenase pathway. Production of heat in mammals is an important physiological event to regulate body temperature in low ambient temperature condition. This thermogenesis process also plays a pivotal role to evoke fever to combat infections. In response to viral and bacterial invasions, synthesis of prostaglandin $E_{2}$ $\left(\mathrm{PGE}_{2}\right)$ is increased specially in brain vasculature (Eskilsson et al., 2017; Matsumura et al., 1998). $\mathrm{PGE}_{2}$ then binds with different EP receptors, such as $\mathrm{EP}_{1}, \mathrm{EP}_{3}$ and $\mathrm{EP}_{4}$, located in the preoptic region of hypothalamus resulting elevation of body temperature (Stitt, 1973). This hyperthermic internal environment is unfavorable to pathogen viability facilitating host defence system to surmount infections. Among these EP receptors, EP3 is the principle binding site of $\mathrm{PGE}_{2}$ for its pyrogenic action. Genetic deletion of $\mathrm{EP}_{3}$ receptors in mice demonstrated complete diminution of febrile response to $\mathrm{PGE}_{2}$ (Ushikubi et al., 1998) or endotoxin whereas knock-out mice lacking $\mathrm{EP}_{1}$ receptors showed attenuated induction of fever (Oka et al., 2003). Despite the general mechanism of thermogenesis in human, rabbit, rat, mouse, etc., various factors influence the overall effect of this physiological process. Among these factors, sex of the animal is one of the foremost factors that manifests distinct variations in animal's body temperature. Young female mice of C57B1/6, C57BL strains are found to show higher core temperature than male; the opposite phenomenon is observed in C3H strain (McLaren, 1961; SanchezAlavez et al., 2011). Such variations in body temperatures between male and female mice are attributed to the subtle neuroanatomical differences in preoptic area of hypothalamus (Kim et al., 2019; Wei et al., 2018) and different rates of $\mathrm{PGE}_{2}$ production (Gregory et al., 2000). Body temperature can also be fluctuated between light and dark part of the day (Sanchez-Alavez et al., 2011). Even holding of a mouse by its tail and scruff of the neck during experiment showed rapid reduction of body temperature in some strains irrespective of their sexes (McLaren, 1961). Phytochemical(s) in methanol extract of $S$. dichotomus must interfere in the COX activity similar to antinociceptive action resulting normalization of body temperature.

The results of the present study confirmed the folkloric use of Schumannianthus dichotomus in pain and fever that warrant comprehensive biochemical and chemical analyses to identify potential bioactive compounds responsible for these pharmacological effects. Also, differential antinociceptive and antipyretic effects based on animal sexes strongly advocates use of both male and female mice in pharmacological investigations of plants.

\section{REFERENCES}

Ahmed, R., Islam, ANMF., Rahman, M., Halim, MA, 2007. Management and economic value of Schumannianthus dichotoma in rural homesteads in the Sylthet region of Bangladesh. IJBSM 3: 252-258.

Akter, A., Basher, MA., Roy, R., Sultana, S., Daula, AFMSU, 2019. Phytochemical content, antioxidant and antidiarrhoeal activities of Limnophila repens. Indones. J. Pharm. 30(3): 187-198.

An, X-L., Zou, J-X., Wu, R-Y., Yang, Y., Tai, F-D., Zeng, S-Y, et al., 2011. Strain and sex differences in anxiety-like and social behaviors in C57BL/6J and BALB/cJ mice. Exp Anim. 60(2): 111-123.

Ballou, LR., Botting, RM., Goorha, S., Zhang, J., Vane, JR, 2000. Nociception in cyclooxygenase isozyme-deficient mice. Proc. Natl. Acad. Sci. U. S. A. 97(18): 10272-10276.

Beery, AK., Zucker, I, 2011. Sex bias in neuroscience and biomedical research. Neurosci. Biobehav. Rev. 35(3): 565-572.

Boussouf, L., Boutennoune, H., Kebieche, M., Adjeroud, N., Al-Qaoud, K., Madani, K, 2017. Anti-inflammatory, analgesic and antioxidant effects of phenolic compound from Algerian Mentha rotundifolia L. leaves on experimental animals. S. Aft. J. Bot. 113: 77-83.

Chen, H., Pu, J., Liu, D., Yu, W., Shao, Y., Yang, G, et al., 2016. Anti-inflammatory and antinociceptive properties of flavonoids 
from the fruits of black mulberry (Morus nigra L.). PloS one 11(4).

Cicero, TJ., Nock, B., Meyer, ER, 1996. Genderrelated differences in the antinociceptive properties of morphine. J. Pharmacol. Exp. Ther. 279: 767-773.

Collier, HOJ., Dinneen, LC., Johnson, CA., Schneider, C, 1968. The abdominal constriction response and its suppression by analgesic drugs in the mouse. Br. J. Pharmacol. Chemother. 32: 295-310.

Davidson, EM., Carlton, SM, 1998. Intraplantar injection of dextrorphan, ketamine or memantine attenuates formalin-induced behaviors. Brain. Res. 785(1): 136-142.

Dina, OA., Aley, KO., Isenberg, W., Messing, RO., Levine, JD, 2001. Sex hormones regulate the contribution of PKC and PKA signaling in inflammatory pain in the rat. Eur. J. Neurosci. 13: 2227-2233.

Dubuisson, D., Dennis, SG, 1977. The formalin test: a quantitative study of the analgesic effects of morphine, meperidine, and brain stem stimulation in rats and cats. Pain. 4(2): 161174.

Eskilsson, A., Matsuwaki, T., Shionoya, K., Mirrasekhian, E., Zajdel, J., Schwaninger, M, et al., 2017. Immune-induced fever is dependent on local but not generalized prostaglandin E2 synthesis in the brain. J. Neurosci. 37(19): 5035-5044.

Evans, WC. 2009. Trease and Evan's Pharmacognosy Ed.^Eds. 16th ed.Nottingham, UK: Saunders Ltd. pp.

Fatehi-Hassanabad, Z., Jafarzadeh, M., Fafehi, M., Razavi-Tossi, MT, 2005. Sex affects the feeling of pain in the mice, possible involvement of nitric oxide. DARU J. Pharm. Sci. 13(3): 116-119.

Ferdous, M., Daula, AFMSU., Naznin, S., Yeasmin, F., Basher, MA, 2020. Analgesic, anxiolytic and sedative-like activities of leaves of Alpinia calcarata Roscoe in mice. J. Med. Plants Res. 14(4): 155-163.

Gomathi, R., Manian, S, 2015. Analgesic and acetylcholinesterase inhibition potential of polyphenols from Scolopia crenata (Flacourtiaceae): An endemic medicinal plant of India. Ind. Crop Prod. 73: 134-143.

Gregory, MS., A.Duffner, L., L.Hahn, E., HsinHsiungTai., E.Faunce, D., J.Kovacs, E, 2000. Differential production of prostaglandin E2 in male and female mice subjected to thermal injury contributes to the gender difference in immune function: possible role for 15-hydroxyprostaglandin dehydrogenase. Cell. Immunol. 205(2): 94102.

Hunskaar, S., Hole, K, 1987. The formalin test in mice: dissociation between inflammatory and non-inflammatory pain. Pain. 30(1): 103-114.

Karim, I., Roy, R., Hoque, MR., Hosen, S., Bhowmik, T., Liya, IJ, et al., 2020. Effect of sex differences in antinociceptive, antipyretic, hypoglycemia, hepatoprotective and antidiarrheal activities in mice model. J. Pharm. Pharmacogn. Res. 8(6): 569-579.

Kepler, KL., Standifer, KM., Paul, D., Kest, B., Pasternak, GW., Bodnar, RJ, 1991. Gender effects and central opioid analgesia. Pain. 45(1): 87-94.

Kim, DW. Yao, Z. Graybuck, LT. Kim, TK. Nguyen, TN. Smith, KA, et al., 2019. Multimodal analysis of cell types in a hypothalamic node controlling social behavior. Cell 179(3): 713-728 e717.

Lander, ES., Linton, LM., Birren, B., Nusbaum, C., Zody, MC., Baldwin, J, et al., 2001. Initial sequencing and analysis of the human genome. Nature 409(6822): 860-921.

Lee, B-W., Park, J-G., Ha, TKQ., Pham, HTT., An, J-P., Noh, J-R, et al., 2019. Constituents of the edible leaves of Melicope pteleifolia with potential analgesic activity. J. Nat. Prod. 82(8): 2201-2210.

Linhart, O., Obreja, O., Kress, M, 2003. The inflammatory mediators serotonin, prostaglandin E2 and bradykinin evoke calcium influx in rat sensory neurons. Neuroscience 118(1): 69-74.

Mandal, RN., Bar, R., Chakrabarti, PP, 2014. 'Pati bet', Schumannianthus dichotomus (Roxb.) Gagnep. - a raw material for preparation of livelihood supporting handicrafts. Indian J. Nat. Prod. Resour. 5(4): 365-370.

Maneenoon, K., Khuniad, C., Teanuan, Y., Saedan, N., Prom-in, S., Rukleng, N, et al., 2015. Ethnomedicinal plants used by traditional healers in Phatthalung Province, Peninsular Thailand. J Ethnobiol. Ethnomed. 11(43): 120.

Matsumura, K., Cao, C., Ozaki, M., Morii, H., Nakadate, K., Watanabe, Y, 1998. Brain endothelial cells express cyclooxygenase-2 during lipopolysaccharide-induced fever: light and electron microscopic 
immunocytochemical studies. J. Neurosci. 18(16): 6279-6289.

McLaren, A, 1961. Some causes of variation of body temperature in mice. Exper. Physiol. 46(1): 38-45.

Mizokami, SS., Arakawa, NS., Ambrosio, SR., Zarpelon, AC., Casagrande, R., Cunha, TM, et al., 2012. Kaurenoic Acid from Sphagneticola trilobata Inhibits Inflammatory Pain: Effect on Cytokine Production and Activation of the NO-Cyclic GMP-Protein Kinase G-ATPSensitive Potassium Channel Signaling Pathway. J. Nat. Prod. 75(5): 896-904.

Mohar, I., Stamper, BD., Rademacher, PM., White, CC., Nelson, SD., Kavanagh, TJ, 2014. Acetaminophen-induced liver damage in mice is associated with gender-specific adduction of peroxiredoxin-6. Redox Biol. 2: 377-387.

Muhammad, A. Khan, B. Iqbal, Z. Khan, AZ. Khan, I. Khan, K, et al., 2019. Viscosine as a Potent and Safe Antipyretic Agent Evaluated by Yeast-Induced Pyrexia Model and Molecular Docking Studies. ACS Omega 4(10): 1418814192.

Neethu, V., Latha, PG., Suja, SR., Vilash, V., Ragesh, R., Shoumya, S, et al., 2017. Hepatoprotective property of Schumannianthus virgatus (Roxb.) Rolfe against D-galactosamine induced hepatotoxicity in wistar rats. Int. J. Adv. Res. 5(7): 2301-2307.

Nguyen, TD., Thuong, PT., Hwang, IH., Hoang, TKH., Nguyen, MK., Nguyen, HA, et al., 2017. Antihyperuricemic, anti-inflammatory and analgesic effects of Siegesbeckia orientalis L. resulting from the fraction with high phenolic content. BMC Complement. Altern. Med. 17(1): 191.

Nieto, FR., Cobos, EJ., Entrena, JM., Parra, A., GarcíaGranados, A., Baeyens, JM, 2013. Antiallodynic and analgesic effects of maslinic acid, a pentacyclic triterpenoid from Olea europaea. J. Nat. Prod. 76(4): 737740.

Nishikawa, S., Yasoshima, A., Doi, K., Nakayama, H., Uetsuka, K, 2007. Involvement of sex, strain and age factors in high fat diet-induced obesity in C57BL/6J and BALB/cA mice. Exp Anim. 56(4): 263-272.

OECD. (2001). Guideline for testing of chemicals. Guidance \#423. Acute oral toxicity- acute toxic class method. Retrieved from https://www.oecd-ilibrary.org
Oka, T., Oka, K., Kobayashi, T., Sugimoto, Y., Ichikawa, A., Ushikubi, F, et al., 2003. Characteristics of thermoregulatory and febrile responses in mice deficient in prostaglandin EP1 and EP3 receptors. J. Physiol. 551(Pt 3): 945-954.

Owoyele, BV., Oguntoye, SO., Dare, K., Ogunbiyi, BA., Aruboula, EA., Soladoye, AO, 2008. Analgesic, anti-inflammatory and antipyretic activities from flavonoid fractions of Chromolaena odorata. J. Med. Plants Res. 2(9): 219-225.

Pace, S., Rossi, A., Krauth, V., Dehm, F., Troisi, F., Bilancia, R, et al., 2017. ¥š†<Sex differences in prostaglandin biosynthesis in neutrophils during acute inflammation. Sci. Rep. 7: 3759.

Pathan, H., Williams, J, 2012. Basic opioid pharmacology: an update. Br. J. Pain 6(1): 11-16.

Report from the Commission to the European Parliament and the council. (2020). Retrieved from Brussels:

Roy, R., Ud Daula, A., Akter, A., Sultana, S., Barek, MA., Liya, IJ, et al., 2019. Antipyretic and antinociceptive effects of methanol extract of leaves of Fimbristylis miliacea in mice model. J. Ethnopharmacol. 243: 112080.

Sajib, NH., Uddin, SB, 2015. Ethnomedicinal Study of Plants in Hathazari, Chittagong, Bangladesh. Pertanika J. Trop. Agric. Sci. 38 (2): 197 - 210.

Sanchez-Alavez, M., Alboni, S., Conti, B, 2011. Sexand age-specific differences in core body temperature of $\mathrm{C} 57 \mathrm{Bl} / 6$ mice. Age (Dordr) 33(1): 89-99.

Siegmund, E., Cadmus, R., Lu, G, 1957. A method for evaluating both non-narcotic and narcotic analgesics. Proc. Soc. Exp. Biol. Med. 95: 729-731.

Sorge, RE. Mapplebeck, JCS. Rosen, S. Beggs, S. Taves, S. Alexander, JK, et al., 2015. Different immune cells mediate mechanical pain hypersensitivity in male and female mice. Nat. Neurosci. 18(8): 1081-1083.

Spruss, A., Henkel, J., Kanuri, G., Blank, D., Püschel, GP., Bischoff, SC, et al., 2012. Female mice are more susceptible to nonalcoholic fatty liver disease: sex-specific regulation of the hepatic AMP-activated protein kinaseplasminogen activator inhibitor 1 cascade, but not the hepatic endotoxin response. Mol. Med. 18(9): 1346-1355.

Stitt, JT, 1973. Prosaglandin E1 fever induced in rabbits. J. Physiol. 232(1): 163-179. 
Subedi, NK., Rahman, S., Akbar, MA, 2016. Analgesic and antipyretic activities of methanol extract and its fraction from the root of Schoenoplectus grossus. Evid. Based Complement. Alternat. Med. 2016.

Sun, N., Zheng, G., He, M., Feng, Y., Liu, J., Wang, M, et al., 2019. Grayanane diterpenoids from the leaves of Rhododendron auriculatum and their analgesic activities. J. Nat. Prod. 82(7): 1849-1860.

Sutradhar, RK., Rahman, AM., Ahmad, M., Bachar, SC., Saha, A., Roy, TG, 2007. Antiinflammatory and analgesic alkaloid from Sida cordifolia Linn. Pak. J. Pharm. Sci. 20: $185-188$

Suzuki, Y., Nakahara, K., Ensho, T., Murakami, N, 2017. Sex difference of hyperinsulinemia in the C57BL/6J-Daruma (obese) mouse. J. Vet. Med. Sci.: 17-0006.

Tomazetti, J. Avila, DS. Ferreira, AP. Martins, JS. Souza, FR. Royer, C, et al., 2005. Baker yeastinduced fever in young rats: characterization and validation of an animal model for antipyretics screening. J. Neurosci. Methods 147(1): 29-35.

Ushikubi, F. Segi, E. Sugimoto, Y. Murata, T. Matsuoka, T. Kobayashi, T, et al., 1998. Impaired febrile response in mice lacking the prostaglandin E receptor subtype EP3. Nature 395(6699): 281-284.
Veldkamp, JF., Turner, IM, 2016. The correct name for Schumannianthus dichotomus (Marantaceae). Kew Bull. 71(47): 1-4.

Wald, C., Wu, C. (2010). Of mice and women: the bias in animal models. In: American Association for the Advancement of Science.

Wang, Y., Chen, P., Tang, C., Wang, Y., Li, Y., Zhang, $\mathrm{H}, 2014$. Antinociceptive and antiinflammatory activities of extract and two isolated flavonoids of Carthamus tinctorius L. J. Ethnopharmacol. 151(2): 944-950.

Waterston, RH., Lindblad-Toh, K., Birney, E., Rogers, J., Abril, JF., Agarwal, P, et al., 2002. Initial sequencing and comparative analysis of the mouse genome. Nature 420(6915): 520-562.

Wei, YC., Wang, SR., Jiao, ZL., Zhang, W., Lin, JK., Li, $\mathrm{XY}$, et al., 2018. Medial preoptic area in mice is capable of mediating sexually dimorphic behaviors regardless of gender. Nat. Commun. 9(1): 279.

Wheeler-Aceto, H., Porreca, F., Cowan, A, 1990. The rat paw formalin test: comparison of noxious agents. Pain. 40(2): 229-238.

Woolfe, G., Macdonald, AD, 1944. The evaluation of the analgesic action of pethidine hydrochloride (demerol). J. Pharmacol. Exp. Ther. 80(3): 300-307. 